Biografistyka Pedagogiczna

Rok 1 (2016) nr 1

ISSN 2543-6112; e-ISSN 2543-7399

DOI: $10.36578 /$ BP.2016.01.05

Izabela Lewandowska*

Sylwia Szkamruk ${ }^{\star \star}$

\title{
Otokar Rudke - życie na polsko-niemieckim pograniczu politycznym, kulturowym i społecznym
}

\section{Otokar Rudke: Living in the Political, Cultural and Social Polish- German Borderlands}

\begin{abstract}
Otokar Rudke was a forest district manager who was living and acting on the verge between political, cultural and social area. He was born in the family of landowners and owners of industrial plants but after World War II he renounced his origin and described himself as a son of a peasant (social borderland). During interwar period he worked in the forest district of Przysucha (Kielce region) and after World War II - in the forest district of Kudypy (Warmia region).

His ancestors came from the Finnish family, whereas he considered himself as a Pole and he was urged to sign Volkslist (German People's List) during German occupation. He refused to do it however he had to work in Warmia region, among many people of the native population (cultural borderland).

In his youth acted in PPS (Polish Socialist Party), after World War II he was a member of PZPR (Polish United Workers Party). However, he was quickly expelled from the Party and was imprisoned by communist authorities and forced to cooperate with SB - Security Service (political borderland).
\end{abstract}

Keywords: Otokar Rudke, strangeness, biography, Przysucha Forest District, forester, family traditions

* Izabela Lewandowska - dr hab., prof. Uniwersytetu Warmińsko-Mazurskiego w Olsztynie, iza.lewandowska@uwm.edu.pl.

** Sylwia Szkamruk-mgr, pracuje w Fundacji Warmia i Mazury w Europie w Olsztynie, inter@ cso.pl. 
Otokar Rudke - bohater naszych rozważań - urodził się 31 marca 1902 r. w Bukowej Górze koło Małogoszczy, w ówczesnym zaborze rosyjskim na Kielecczyźnie, dzieciństwo spędził w Łodzi, młodość ponownie w Kieleckiem, a lata dojrzałe, po drugiej wojnie światowej na Warmii. Zmarł w Warszawie, u swojej córki, w 1993 r. Jest to postać nietuzinkowa, niejednowymiarowa, prowadząca swój żywot w trudnych czasach dwóch wojen światowych, okrutnych czasów stalinowskich i socjalistycznej codzienności. Mimo przeciwności Otokar Rudke zachował poczucie godności, narodową polską tożsamość i rzetelność w pracy, którą wykonywał bez zarzutu. Przez całe życie związany był z przyrodą, pełnił funkcje leśniczego, a następnie nadleśniczego w lasach Przysuchy, a po wojnie w Kudypach, w okolicach Olsztyna. Jako nadleśniczy spotykał wielu ludzi, z którym współpracował - zarówno w czasach okupacji niemieckiej, jak i w okresie powojennym na terenie Warmii. Przekazał swoje wartości wnukom, którzy zgromadzili pokaźny zbiór dokumentów i pamiątek. Na ich podstawie powstała biografia. Także w tym szkicu wykorzystywane są dokumenty z prywatnego archiwum rodziny Sługockich (wnuków Rudke), Instytutu Pamięci Narodowej oraz Archiwum Dyrekcji Lasów Państwowych w Olsztynie. Niniejszy tekst jest rozszerzeniem dotychczasowych informacji o nadleśniczym Rudke, a przede wszystkim próbą ukazania jego intrygującej osobowości, o której nigdy, w żadnych dostępnych nam publikacjach, nikt się nie wypowiadał. Pogranicza i tożsamości, które próbowałyśmy wyodrębnić i nazwać, wzajemnie się przenikają, nie są jednoznaczne, stąd też podział wewnątrz artykułu jest w dużej mierze umowny.

\section{Pogranicze polityczne / tożsamość historyczna i obywatelska}

Badacze wielokrotnie definiowali „pogranicze”, używając do tego wielu określeń, często komplementarnych. Jedną z definicji zaproponował socjolog Andrzej Sakson: „pogranicze stanowi obszar przenikania się kultur sąsiednich narodów - polskiego i niemieckiego w warunkach podrzędności lub równorzędności, ale bez niszczenia związków z własnym obszarem narodowym" ${ }^{\prime 2}$. Definicja ta najtrafniej obrazuje życie Otokara Rudke, które przebiegało w czasach dwóch wojen światowych, dlatego też polityka odcisnęła znaczne piętno na jego działalności, a aspekt pogranicza politycznego przewija się przez całe jego życie.

1 I. Lewandowska, S. Szkamruk, Otton Alfons (Otokar) Rudke 1902-1993. Początki powojennego leśnictwa, towiectwa i bobrownictwa na Warmii, Olsztyn 2015.

2 A. Sakson, Mazurzy - społeczność pogranicza, Poznań 1990, s. 23. 
Rudke żył na przestrzeni kilku epok - urodził się pod zaborami, kształcił w łódzkich szkołach, od 1912 r. uczęszczał do Carskiego Gimnazjum Filologicznego. Miał ośmioro rodzeństwa. Jego rodzice byli patriotami, tak też wychowywali swoje dzieci. Rodzina była jednym z najistotniejszych elementów określających tożsamość historyczną i obywatelską naszego bohatera. „Rodzina, w której wszyscy członkowie mają rodowód polski, zachowuje przywiązanie do języka, religii, obrzędów i tradycji, wykazuje zainteresowanie sprawami Polski, Polaków, Polonii, niezależnie od uwarunkowań społeczno-politycznych i ekonomicznych"3.

Otokar wraz z braćmi działał w Polskiej Partii Socjalistycznej, nosząc konspiracyjną pocztę (bibułę) w tornistrze jako uczeń4. W swoim życiorysie wspominał: „W roku 1918 porywem młodości i kolegów uciekłem z domu w czasie rozbrajania Niemców” ${ }^{\prime 2}$, było to 11 listopada 1918 r. Tuż po uzyskaniu niepodległości przez Polskę Otokar ze swoimi przyjaciółmi harcerzami pojechał, jak napisał, „na odsiecz Lwowa”. Podając fałszywą datę urodzenia (w 1918 r. miał szesnaście lat), wstąpił do formułującego się Wojska Polskiego. Jego służba wojskowa w 7. Pułku Artylerii Konnej trwała niecały rok ${ }^{6}$, po czym w 1919 r. został zwolniony z wojska. Pisał: „Po otrzymaniu lekkiej rany na froncie pod Lwowem powróciłem do domu i kształciłem się dalej"7. Wszyscy bracia, z wyjątkiem najstarszego, zmarłego w 1915 r., służyli w legionach marszałka Józefa Piłsudskiego, a po pierwszej wojnie światowej w Wojsku Polskim. W 1919 r. ukończył szkołę Podchorążych Artylerii w Rembertowie i jako konny artylerzysta brał udział w wielu bitwach, w czasie kampanii $1920 \mathrm{r}$. był dwukrotnie ranny. Zdemobilizowany został w stopniu porucznika. To pierwszy etap życia Rudke - walka na frontach pierwszej wojny światowej i wojny z Rosją Radziecką o granice naszego państwa.

Drugim etapem jego życia jest okres międzywojenny, czas stabilizacji w odrodzonym państwie polskim. Wtedy ukończył Wyższą Szkołę Gospodarstwa Wiejskiego i został leśnikiem, a następnie nadleśniczym w lasach przysuskich.

3 A. Chodubski, $O$ tożsamości polonijnej, w: Tożsamość kulturowa, kwestie narodowościowe i polonijne, red. A. Chodubski, Torun 1998, s. 23.

4 Instytut Pamięci Narodowej, Oddział w Białymstoku, zbiory zdigitalizowane [dalej: IPN/ Bi/oo88/550/D], Życiorys z dn. 27 stycznia 1946, s. 36.

5 IPN/Bi/oo88/550/D, Życiorys z dn. 2 III 1953, s. 17.

6 Archiwum Regionalnej Dyrekcji Lasów Państwowych [dalej: ARDLP], Życiorys, Olsztyn, 7 czerwca 1945.

7 ARDLP, Ankieta personalna i życiorys, Kudypy, 26 stycznia 1955. 
Sytuacja polityczna zmieniła się wraz z wybuchem drugiej wojny światowej. Tu zaczął się kolejny okres - walka z okupantem niemieckim. Rudke niezwłocznie pragnął zaciągnąć się do wojska, udał się pieszo na wschód, nie udało mu się jednakże zaciągnąć, a po opanowaniu Kresów Wschodnich przez Armię Radziecką musiał wracać do domu. Był zdeterminowany, świadczą o tym słowa, które napisał: „Po rozejrzeniu się w sytuacji postanowiłem za wszelką cenę podjąć walkę z okupantem”" ${ }^{8}$. Jako leśnik na terenach Kielecczyzny czynnie służył ojczyźnie. Już w listopadzie 1939 r. nawiązał kontakt i został zaprzysiężony jako oficer Służby Zwycięstwu Polski (szP), która przekształciła się kolejno w Związek Walki Zbrojnej (zWZ) i wreszcie w Armię Krajową (AK). Działał pod pseudonimem „Orzeł” i pełnił ważne dla oddziału funkcje kwatermistrzowskie, aprowizacyjne i wywiadowcze. Rudke czynnie współpracował z partyzanckimi oddziałami słynnego Henryka Dobrzańskiego „Hubala”, któremu pomagał finansowo (zachował się dokument potwierdzający przekazanie znacznej sumy pieniędzy, karabinów maszynowych, amunicji) ${ }^{10}$.

Po śmierci „Hubala” nadleśniczy Rudke współpracował z oddziałami Gwardii Ludowej, a także Narodowych Sił Zbrojnych - dbał o zabezpieczenie noclegu żołnierzom, aprowizacji, opatrywania rannych, w czym pomagały mu żona i córka, oraz w nawiązywaniu kontaktów z miejscowymi ${ }^{11}$. Niezwykle ciężki i niebezpieczny był okres operacji „Burza”, 1944 r. Większość żołnierzy walczących w lasach przysuskich była ranna i wycieńczona, wymagała natychmiastowej opieki. W czasie koncentracji AK w lasach przysuskich i rozwadowskich rozlokowało się kilka tysięcy ludzi. W swoim życiorysie wspominał:

Otrzymałem wtedy polecenie dopomożenia w aprowizacji oddziałów. Zadanie wykonałem: kilka młynów dostarczyło znaczne ilości mąki, a przy pomocy miejscowej organizacji ze Skarżyska skonfiskowałem w dwóch majątkach (liegenschaftach) 14 wołów i 2 wozy owsa ${ }^{12}$.

8 O. Rudke, Przysięgę odbierał hubalczyk, w: Gniewnie szumiał las. Wspomnienia leśników polskich 1939-1945, wybór i oprac. J. Gmitruk, W. Lipko, P. Matusak, Warszawa 1982, s. 46.

9 Henryk Dobrzański, ps. „Hubal” (1897-1940) - major kawalerii Wojska Polskiego, sportowiec, jeden z pierwszych dowódców partyzanckich w czasie drugiej wojny światowej.

10 „Oddziałom Hubala przekazał 2000 zł (przed wojną to spora suma - można było kupić 20 krów)" - W. Szumarski, Wspomnienia o pierwszym powojennym nadleśniczym Nadleśnictwa Kudypy, maszynopis w zbiorach autorek.

11 O. Rudke, Przysięgę odbierał hubalczyk, s. 49-50.

12 Tamże, s. 50. 
Wielkim wyzwaniem i dla Otokara i jego małżonki Janiny Rudke był czas po Powstaniu Warszawskim, gdy przez Rozwady przelała się rzeka uchodźców, wynędzniałych, głodnych, w łachmanach. Pomoc tym ludziom wymagała wielkiego wysiłku i hartu ducha. Pamiętać należy, że był to czas działań frontowych. Niedługo pojawiły się radzieckie oddziały. „Do czasu wyzwolenia, to jest do 19 stycznia 1945 roku, współpracowałem z oddziałem partyzanckim porucznika «Osucha» Lipińskiego". Przez władze polskie za zasługi w czasie okupacji został awansowany do stopnia kapitana i odznaczony Krzyżem Partyzanckim i Krzyżem Armii Krajowej ${ }^{13}$. Jednakże w związku z narastającą nagonką na żołnierzy Armii Krajowej Rudke w późniejszych swoich życiorysach pomijał ten temat, podobnie jak przemilczał walkę przeciwko Armii Czerwonej w latach 1919-1920.

Okres powojenny to zupełnie nowy etap życia Otokara Rudke w zupełnie innych realiach politycznych. Po wkroczeniu wojsk sowieckich na tereny centralnej Polski Otokar był poszukiwany przez Urząd Bezpieczeństwa ${ }^{14}$. Wyjechał do Łodzi, gdzie nawiązał kontakt z kolegami leśnikami; jeden z nich pomógł mu uzyskać w Ministerstwie Leśnictwa przydział do pracy na Warmii, w Olsztynie. Skierowanie uzyskał w maju 1945 r. i już 15 maja został mianowany nadleśniczym w Kudypach, gdzie zamieszkał w domu byłego nadleśniczego Otto Krügera [w polskich tekstach pisane jako Kriegera $]^{15}$, który był tam ostatnim niemieckim nadleśniczym. Czasy, w których przyszło mu żyć po wojnie, były nadal niebezpieczne, niepewne. Oskarżony przez UB o współpracę z AK, NSZ i z całym podziemiem niepodległościowym, przez wiele lat był inwigilowany. Ponownie polityka wkroczyła w jego życie osobiste. Cierpiała na tym żona i córka, szczególnie gdy przebywał w więzieniu.

Wraz z zakończeniem okresu stalinowskiego w Polsce jego życie się ustabilizowało. Mimo iż na głos się do tego nie przyznawał, był dumny ze swojego życia. We wspomnieniach napisał: „Nazywam się Otton Otokar Rudke i jestem synem ziemi Kieleckiej z dziada i pradziada. Za wolność mojej Ojczyzny walczyłem w dwóch wojnach 1918-1920 i 1939-1945”. Nigdy nie zajmował się polityką, mawiał: „Pracy z polityką nie mieszaj". Jednakże z dokumentacji wynika, iż należał do partii. Od 1942 r. był członkiem Polskiej Partii Robotniczej (PPR), potem Polskiej Zjednoczonej Partii Robotniczej (PZPR), skąd w 1950 r. został wydalony przez byłego sekretarza Komitetu Powiatowego

13 W. Szumarski, Wspomnienia o pierwszym powojennym nadleśniczym.

14 Urząd Bezpieczeństwa (UB) - powszechnie używane określenie organów bezpieczeństwa państwa, funkcjonujących w Polsce w okresie stalinizmu (1944-1956).

15 W. Szumarski, Wspomnienia o pierwszym powojennym nadleśniczym. 
PZPR. Oskarżono go o występowanie z bronią podczas okupacji przeciwko członkom PPR, ponad to o to, iż „W życiu społeczno-politycznym udziału nie brał, jak również jako członek nie przejawiał żadnej aktywności po linii Partii, przy czym tłumaczył się brakiem czasu z powodu nawału pracy po linii zawodowej" ${ }^{16}$. W latach 1945-1953 działał w Związku Zawodowym Pracowników Leśnictwa i Przemysłu Leśnego (ZZPLiPL). W 1950 r. wstąpił do Naczelnej Organizacji Technicznej (NOT).

Trzeba pamiętać, że początek lat pięćdziesiątych w całej Polsce, a szczególnie na Warmii i Mazurach, był okresem bardzo trudnym, również ze względów politycznych. Wojewodą olsztyńskim w czasach stalinowskich był Mieczysław Moczar. Wszędzie szerzyło się donosicielstwo i inwigilacja urzędników. UB chciał wykorzystać znajomości Otokara Rudke wśród wyższych urzędników państwowych i leśnych i zmusić go do współpracy. W osławionych polowaniach u Rudke w Kudypach uczestniczyli np. prezydent Bolesław Bierut, marszałek Michał Rola-Żymierski, minister bezpieczeństwa publicznego Stanisław Radkiewicz, wiceminister obrony narodowej Marian Spychalski oraz wojewoda olsztyński gen. Mieczysław Moczar ${ }^{17}$. Rudke stanowił dla UB

[...] cenną wartość operacyjną, gdyż jako człowiek o wyższym wykształceniu ma możność bywania w różnym otoczeniu, a przeważnie w otoczeniu takim, o których nasze organa interesują się. W dodatku, iż wywodzi się z rodziny arystokratycznej miejskiej i jego bracia do 1939 roku zajmowali poważne stanowiska po różnych instytucjach mając również wyższe wykształcenie ${ }^{18}$.

Ostatecznie po wielogodzinnych przesłuchaniach i zgromadzeniu wielu zarzutów Otokar Rudke „podpisał zobowiązanie o współpracy z organami bezpieczeństwa publicznego twierdząc, że zadanie powierzone mu będzie wykonywał sumiennie, po czym dokonano formalności związanych z werbunkiem, tj. przejęcie życiorysu napisanego własnoręcznie" ${ }^{\prime 19}$. Przyjął pseudonim „Orsza” i został informatorem UB od marca 1953 roku $^{20}$. Po dwóch latach wykreślono go z czynnej sieci agenturalnej, ponieważ, jak zapisano:

16 IPN/Bi/oo88/550/D, Pismo do Naczelnika Wydziału III-go wUBP w Olsztynie, Barczewo, 19 sierpnia 1952, s. 70; tamże, Pismo do Wydziału III-go wUBP w Olsztynie, Barczewo 23 października 1951, s. 69.

17 IPN/Bi/oo88/550/D, Pismo do Naczelnika Wydziału III-go wUBP w Olsztynie, Barczewo,19 sierpnia 1952, s. 70.

18 IPN/Bi/oo88/550/D, Ocena werbunku, 1953, s. 12.

$19 \mathrm{IPN} / \mathrm{Bi} / 0088 / 550 / \mathrm{D}$, Plan werbunku, 1953, s. 12.

20 IPN/Bi/oo88/550/D, Zobowiązanie, 2 marca 1953, s. 15. 
Rudke nie ma żadnej możliwości rozpracowania interesujących nas osób. Analizując teczkę pracy [operacyjnej] stwierdza się, że od roku nie przekazał żadnych materiałów osób wrogich, a tylko podawał materiały, które można uzyskać drogą oficjalną, ostatnio unika spotkań, a jak przyjdzie, nie przekazuje materiałów, tłumacząc tym, że nigdzie nie chodzi ${ }^{21}$.

W uzasadnieniu stwierdzono, że „cel werbunku wymienionego był w ogóle niesłuszny, a tylko towarzysz [Tadeusz] Podgórski, werbując go, miał na celu podciągnięcie kreski w tablicy wyników pracy operacyjnej"22. Teczka została przekazana do archiwum Departamentu x Wydziału XI.

\section{Pogranicze społeczne / tożsamość społeczna i osobista}

Tożsamość ma dwa podstawowe znaczenia, które oddają osobowość Otokara Rudke:

1) bycie kimś, kto pozostaje „tym samym”, czyli inaczej, kto „kontynuuje” siebie, trwanie cech danej osoby mimo upływu czasu i na przekór zmiennym okolicznościom życia;

2) bycie kimś, kto „jest odróżniany" w pewien szczególny sposób od innych, cechy osobowe danej osoby tę odrębność konstytuują ${ }^{23}$.

Otokar Rudke, mimo niemieckobrzmiącego nazwiska Rudke vel Rutke, czuł się Polakiem. Cała rodzina od pokoleń uważała się za Polaków. Pradziadek Otokara, Fryderyk, pod koniec XVIII w. przybył do Polski z terenów dzisiejszej Finlandii. Od XIX w. rodzina Rudke była przede wszystkim właścicielami ziemskimi w rejonie Piotrkowa, Włoszczowej i Radomia. Rudkowie byli spokrewnieni z rodziną Mannerheimów, z której wywodził się późniejszy marszałek i prezydent Finlandii Carl Mannerheim ${ }^{24}$. Pisownia nazwiska nie była jednakowa, część rodziny używała nazwiska Rudke, a część Rutke. Tylko brat Otokara, August, używał pełnego nazwiska Rudke vel Rutke i tak się nazywają jego potomkowie. Rodzina była wyznania ewangelicko-augsburskiego. W 1905 r. ojciec Otokara, Jan, sprzedał majątek i przeniósł się z rodziną do Łodzi, gdzie kupił fabrykę włókienniczą (niciarnię) przy ulicy Prywatnej 4 (obecnie ul. Moniuszki).

21 IPN/Bi/oo88/550/D, Postanowienie o przekazaniu teczki personalnej do archiwum, br. daty, s. 92. 22 IPN/Bi/oo88/550/D, Charakterystyka informatora ps. „Orsza”, Olsztyn, 3 maja 1955, s. 91.

23 Z. Bokszański, Tożsamości zbiorowe, Warszawa 2006, s. 37.

24 Carl Gustaf Emil Mannerheim (1867-1951) - baron, fiński dowódca wojskowy, generał-lejtnant Armii Imperium Rosyjskiego, marszałek Finlandii, polityk, regent Królestwa Finlandii (1918-1919), prezydent Finlandii (1944-1946). 
Fabrykę maszyn do szycia „The Kempisty - Kasprzycki Company” miał do spółki z Janem Kempistym Józef Kasprzycki, kuzyn żony Otokara, Janiny z domu Kasprzyckiej.

Początkowo Otokar pracował jako nadleśniczy w majątku rodziny Dembińskich, sprawując pieczę nad lasami Przysuchy i Rozwady. W 1936 r. wydzierżawił z zamiarem szybkiego wykupienia zaniedbany majątek Rozwady-Alfredów. Gospodarząc tam, zajmował się nie tylko rolnictwem i leśnictwem, ale założył imponujące swą powierzchnią stawy rybne. Otokar i Janina Rudke za sprawą gospodarstwa w Rozwadach z ciągu kilku zaledwie lat osiągnęli sukces i zyskali uznanie wśród okolicznego ziemiaństwa. Warto też wspomnieć, że w Rozwadach hodowane były konie krwi arabskiej pochodzące ze słynnych stajni księcia Romana Władysława Sanguszki. Otokar był doskonałym jeźdźcem, jego córka również chętnie jeździła konno. Zachowała się opinia wystawiona mu przez właścicielkę Helenę Mycielską, świadcząca o jego nienagannej postawie i rzetelnym wykonywaniu swoich obowiązków:

Jako Nadleśniczy prowadził cały majątek leśny i rybny w wzorowym porządku i wielką uczciwością. Las jodłowo-dębowy był racjonalnie eksploatowany i odnawiany przez podsiewy. Planowa gospodarka dała jak najlepsze wyniki. W czasie okupacji dzielnie ochraniał las przed zachłannością niemiecką, wyrębując minimalne ilości drewna, potrzebnego dla miejscowej ludności ${ }^{25}$.

Pytany o swój stosunek do pracy zawodowej Otokar Rudke zawsze podkreślał, iż jest pracownikiem leśnym. Jednakże działał również jako radny, przewodniczący rady gminnej gminy Krzczonów, przewodniczący rady nadzorczej, następnie prezes zarządu Spółdzielni Rolniczo-Handlowej w Opocznie. Zawsze miał na względzie pomoc i poradę najbiedniejszej ludności wiejskiej, stąd też jego udział w Samopomocy Chłopskiej ${ }^{26}$. Ze wspomnień jego wnuka, Mirosława Kazimierza Sługockiego, dowiadujemy się, iż Otokar Rudke był człowiekiem stanowczym, konkretnym, nielubiącym się powtarzać: „Białe to białe, czarne to czarne”. Zawsze elegancki, zadbany, zadawał szyku, chodząc co dzień w mundurze i oficerkach czy jeżdżąc konno. Jego największą pasją było łowiectwo i tu również przyświecała mu życiowa maksyma: „To, iż się poluje, nie znaczy, że się zabija". W 1936 r. Otton został aktywnym członkiem Polskiego Związku Łowieckiego, w którym działał przez całe życie.

25 ARDLP, Zaświadczenie Heleny Mycielskiej potwierdzone przez notariusza, Warszawa, 13 września 1948.

26 ARDLP, Kwestionariusz, Kudypy, 23 stycznia 1947. 
Pozwoliło to na zgromadzenie „sporej ilości wieńców jelenich i parostek rogaczy, a określonych wg wieków i całą masą zrzutów". Nie była to tylko pasja czy chęć poszerzenia własnych, domowych zbiorów trofeów myśliwskich, ale przyświecały mu szczytne idee: zbiory były wypożyczane jako eksponaty na przeróżnych pokazach, zebraniach, spotkaniach z mieszkańcami niezwiązanymi z myślistwem lub samymi myśliwymi w celach kształcenia w sztuce myśliwskiej. W 1937 r. Rudke uczestniczył w Międzynarodowej Wystawie Łowieckiej w Berlinie, co było wówczas wydarzeniem bardzo prestiżowym ${ }^{27}$. Udział w tej wystawie sprawił, że w późniejszych czasach Otokar Rudke otaczany był szacunkiem.

W okresie wojennym nadleśniczy miał wiele okazji, aby okazywać pomoc potrzebującym. Oprócz udzielania wsparcia partyzantom (o czym była już mowa wcześniej) pomagał także Żydom. We wspomnieniach zachowało się kilka epizodów świadczących o jego postawie. Na przykład latem 1943 r., kiedy zaczęto wywozić Żydów do obozów śmierci, zaszła do niego Żydówka z Drzewicy i poprosiła o pomoc. Postarał się dla niej o wiejski przyodziewek, a perhydrolem utlenił jej włosy na blond. Wyczekiwał na transport z Opoczna do Niemiec, wywożący ludzi na przymusowe roboty. Udało mu się wysłać ową Żydówkę wraz z jej bratem i bratową. Pisywała potem do niego z Niemiec listy. Cała trójka, a nawet czwórka, bo w Niemczech jej bratowa urodziła syna, powróciła po wojnie do Polski i osiedliła się w Łodzi. Po powrocie odwiedzili go i dziękowali za ocalenie. Później rodzina ta wyemigrowała do Palestyny. Inną sytuacją było przybycie w okoliczne lasy oddziału partyzanckiego złożonego z samych Żydów, „wśród nich było kilku znajomych Żydów z Gielniowa, Drzewicy i Radomia. Nakarmiłem ich i w czym mogłem, udzieliłem pomocy. Jeszcze przez dłuższy czas Żydzi odwiedzali nas mniejszymi grupkami lub pojedynczo"28. W spisanych wspomnieniach córki i wnuka Otokara czytamy, że przez cały czas okupacji niemieckiej Otokar wraz z żoną Janiną pomagali ukrywającym się Żydom. Były to nie tylko trzy osoby opisane przez Otokara we wspomnieniach, ale dziesiątki ratowanych i przekazywanych dalej Żydów. Wiele z nich spędziło w leśniczówce Rozwady dłuższy czas. Byli wśród nich mieszkańcy okolicznych miasteczek, uciekinierzy z Łodzi i kierowani z Warszawy przez siostry nazaretanki, koleżanki córki Celiny, byli wśród nich Eisenman, Anna Katz, Alicja Kirkien²9.

27 W. Fafiński, Referat wygłoszony na xxx lecie koła, http://www.kudypy.olsztyn.pl/index.php/ historia-kultura/41-historia/74-referat-wygoszony-na-xxx-lecie-kola-, dostęp: 28.03.2015. 28 P. K. Sługocki, Wspomnienia o dziadku, Warszawa 2015, maszynopis w zbiorach autorek. 29 Tamże. 
Po wojnie zmieniła się nie tylko sytuacja polityczna, ale także społeczna. Nie można już było przyznawać się do ziemiańskiego pochodzenia, trzeba było wyrzec się swoich zachowań i dobrego wychowania. Było to niewątpliwie trudne dla Otokara Rudke. Jego pochodzenie miało wpływ na jego nienaganne wychowanie, pańskie maniery i przywiązanie do rodzinnych wartości. Niestety w czasach stalinowskich nie przyznawał się do swojego pochodzenia, a wręcz je fałszował, pisząc, że pochodzi z rodziny chłopskiej, a rodzice posiadają kilka hektarów ziemi. To także pokazuje jego rozdarcie na gruncie społecznym. Niektórych jednak nawyków nie dało się wyeliminować. Mamy tego przykład w donosach miejscowych robotników leśnych do UB, w ich oczach Rudke zachowywał się jak „pan”.

Przedwojenne wychowanie Otokara Rudke, nienaganne maniery, wyznawane wartości, jego zawsze elegancki wygląd przyczyniały się do tego, że wygłaszano wiele nieprzychylnych opinii na temat jego „pańskiego” zarządzania nadleśnictwem. Jednocześnie cały czas UB poszukiwał dowodów jego winy. Oficer operacyjny UB nawiązał kontakty z dwoma informatorami, którzy stwierdzili, że

[...] jest to człowiek na wysokim poziomie intelektualnym, szybko spostrzegawczy, energiczny, cieszy się wysokim autorytetem wśród elementu przez nas zainteresowanego [...]. Jest pewny siebie, ambitny i w zupełności nadaje się do wykorzystania go przez organa BP [Bezpieczeństwa Publicznego ${ }^{30}$.

Aby zgromadzić odpowiedni materiał dowodowy, zebrano relacje wielu świadków mających kontakt z Rudke jeszcze przed wojną i mogących go oczernić. W dokumentach IPN widnieją następujące zarzuty: współpracował z Niemcami, przyjaźnił się z nimi; na libacje zapraszał niemiecką żandarmerię; do Polaków był wybitnie wrogo ustosunkowany; stał na czele Narodowych Sił Zbrojnych, a jego oddział doprowadził do śmierci trzech mężczyzn; znęcał się nad swoimi robotnikami leśnymi w okrutny sposób; byli źle wynagradzani; nadużywał swojej funkcji nadleśniczego, wykorzystując podwładnych do pracy w prywatnym gospodarstwie; kazał siebie tytułować „dziedzicem”; żył ponad stan, był bogaty; uznawany był za kobieciarza ${ }^{31}$. Oprócz wyżej

30 IPN/Bi/oo88/550/D, Uwagi o osobistym zetknięciu się z kandydatem, 1953, s. 7.

31 IPN/Bi/o088/550/D, Uwagi o osobistym zetknięciu się z kandydatem, 1953, s. 7; tamże, Pismo do Szefa Urzędu Bezpieczeństwa Publicznego w Olsztynie, 1953, s. 6; tamże, Protokół przesłuchania świadka [br. daty], s. 5; tamże, Charakterystyka, Olsztyn, 3 kwietnia 1951, s. 65; tamże, Pismo do Naczelnika Wydziału III-go wUBP w Olsztynie, Barczewo, 19 sierpnia 1952, s. 70. 
wymienionych zarzutów, był podejrzany o działalność przestępczą i wrogą ze względu na posiadanie większej ilości broni ${ }^{32}$.

Mimo że Otokar Rudke był rozpracowywany przez Służby Bezpieczeństwa, sam starał się żyć normalnie i udzielać się zawodowo. Funkcję łowczego powiatowego pełnił do 1948 r. Corocznie wyjeżdżał na pokazy trofeów myśliwskich i uczestniczył w organizowaniu komisji konkursowych, na które był często zapraszany przez Mazurską Wojewódzką Radę Łowiecką ${ }^{33}$. Był też chętnie typowany jako organizator kursów szkoleniowych przygotowujących kadry selekcjonerów, wybierany na prelegenta kursu i członka komisji egzaminacyjnej. W 1946 r. został powołany do Komisji Dyscyplinarnej przy Dyrekcji Lasów Państwowych Okręgu Mazurskiego w Olsztynie ${ }^{34}$. Świadczy to o jego wysokiej ocenie moralnej przez najwyższe władze leśne w regionie.

7 lipca 1955 r., w dowód doceniania zasług, Ottokar Rudke otrzymał pismo z Polskiego Związku Łowieckiego z siedzibą w Warszawie z podziękowaniami:

Prezydium Naczelnej Rady Łowieckiej, doceniając w pełni wieloletnią pracę społeczną Kolegi jako wykładowcy na kursach dla kandydatów na członków PZŁ oraz na kursach dla selekcjonerów, a także jako przewodniczącego komisji oceny trofeów łowieckich i organizatora pokazu tych trofeów w roku bieżącym, składa niniejszym Koledze podziękowanie za bezinteresowny a tak owocny trud poniesiony dla dobra Ludowego Łowiectwa Polskiego ${ }^{35}$.

Nadleśniczy Rudke zapisał się w historii Nadleśnictwa Kudypy przede wszystkim jako ten, który przeprowadził pełną inwentaryzację lasu na terenie nadleśnictwa. Rozpoczął też na niespotykaną skalę zalesianie gruntów porolnych ${ }^{36}$. Jednocześnie od samego początku pracy w leśnictwie Kudypy włączył się czynnie w ochronę bobrów. To jemu zawdzięczamy utworzenie w 1947 r. rezerwatu tych zwierząt na rzece Pasłęce. Plan z granicami projektowanego rezerwatu obejmował leśnictwa Bobry i Żelazowice wraz z jeziorem Żelaznym i enklawą Nowy Młyn. Rudke długo i wytrwale dążył do celu. Wszystkie jego powojenne wysiłki zmierzały ku temu, aby odbudować populację

32 IPN/Bi/oo88/550/D, Plan werbunku, 1953, s. 8.

33 Archiwum Prywatne Rodziny Rudke i Sługockich [dalej: APRRs], Pismo Mazurskiej Wojewódzkiej Rady Łowieckiej, Olsztyn, 2 grudnia 1950.

34 ARDLP, Pismo Ministra Leśnictwa do O. Rudke, Łódź, 11 stycznia 1946.

35 APRRS, Pismo Polskiego Związku Łowieckiego, Naczelnej Rady Łowieckiej, Warszawa, 7 lipca 1955.

36 W. Szumarski, Wspomnienia o pierwszym powojennym nadleśniczym. 
bobrów, która za czasów niemieckich była duża, jednakże została doszczętnie wytrzebiona $^{37}$. Od 1956 r. Otokar przestał pracować w Nadleśnictwie Kudypy, a objął stanowisko kierownika Rezerwatów Bobrowych w Dłużniewie (dzisiejszy Łęgucki Młyn) ${ }^{38}$. Oficjalnie był zatrudniony w zarządzie Ochrony Przyrody Ministerstwa Leśnictwa na stanowisku kierownika Ośrodków Hodowli Bobrów województwa olsztyńskiego, białostockiego i gdańskiego, z siedzibą w Dłużniewie, powiat Ostróda. Jego praca polegała na penetrowaniu rozległego terenu rezerwatu ${ }^{39}$.

Cały czas jednak był doceniany jako leśnik i myśliwy. Udzielał się w pracach Mazurskiej Wojewódzkiej Rady Łowieckiej, przez którą był zapraszany do Komisji Oceny Poroży zwierzyny płowej. Został też powołany do Komisji Egzaminacyjnej dla selek-

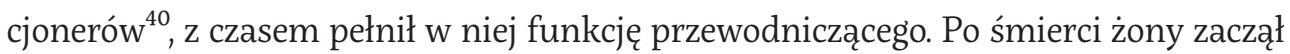
podupadać na zdrowiu, chociaż był czynny zawodowo do $1969 \mathrm{r}$. W końcu zamieszkał w skromnej leśnej osadzie w Biesalu, która po wielu perypetiach, została mu sprzedana $^{41}$.

\section{Pogranicze kulturowe / tożsamość narodowa i regionalna}

Socjolog Antonina Kłoskowska napisała, iż

życie na pograniczu kultur może mieć dwojaki wpływ na świadomość własnego narodowego określenia: albo wyostrza ono tę świadomość i wywołuje postawy obronne wobec narodowości i kultury obcej, albo przeciwnie - powodując mieszanie się kulturowych wpływów prowadzi do ich amalgamacji i niejasnego, złożonego, narodowego samookreślenia lub braku wszelkiego wyraźnego określenia (zjawisko „tutejszości” czy „krajowości”) ${ }^{42}$.

37 Autorki napisały artykuł Bobry i ludzie - wspólne oddziaływanie w środowisku historycznym i przyrodniczym Warmii i Mazur, w którym szczegółowo omówiły rolę Otokara Rudke w tworzeniu rezerwatów bobrowych. Artykuł jest złożony do druku w czasopiśmie „Zeszyty Naukowe Ostrołęckiego Towarzystwa Naukowego".

38 ARDLP, Pismo dyrektora A. Młynarka do O. Rudke, Olsztyn, 6 lipca 1965.

39 ARDLP, Pismo O. Rudke do Ministerstwa Leśnictwa i Przemysłu Drzewnego, Olsztyn, 20 kwietnia 1964; tamże, Notatka służbowa, Olsztyn, 19 grudnia 1966; tamże, Pismo Dyrektora Zarządów Lasów Państwowych Z. Śmiechowskiego do O. Rudke, Olsztyn, 21 grudnia 1966.

40 APRRS, Pismo mwrŁ do O. Rudke, Olsztyn, 3 września 1958.

41 W. Szumarski, Wspomnienia o pierwszym powojennym nadleśniczym.

42 A. Kłoskowska, Tożsamość i identyfikacja narodowa w perspektywie historycznej i psychologicznej, „Kultura i Społeczeństwo”, 36 (1992) nr 1, s. 139. 
Życie na styku wielu kultur było widoczne w biografii Otokara Rudke. Pochodził z fińskiej rodziny, wychowany jako Polak w wieloetnicznej Łodzi, kształcił się w carskim gimnazjum, w którym obowiązywał język rosyjski, utożsamiany z Niemcem w czasie okupacji, pomagał ukrywającym się Żydom i współpracował po wojnie z Warmiakami. Na życie jednego człowieka to wystarczająco dużo, aby móc stwierdzić, iż żył na kulturowym pograniczu zarówno terytorialnym (rosyjskim, polskim, niemieckim, znowu polskim, a szczególnie warmińskim), językowym - oprócz języka polskiego znał biegle rosyjski i niemiecki, a także religijnym - urodzony w rodzinie ewangelicko-augsburskiej czuł się katolikiem.

Jego narodowa polska tożsamość nie budzi zastrzeżeń, nieco inaczej można ocenić jego tożsamość regionalną. Wydaje się, że wszędzie, gdzie przyszło mu żyć i pracować, angażował się w pracę dla dobra tego skrawka ziemi. Zatem jego tożsamość regionalna była płynna - zależała od aktualnego miejsca życia. Kiedy w okresie międzywojennym pracował dla hrabiny Zofii z Tyszkiewiczów Henrykowej Dembińskiej, a od 1938 r. dla jej najmłodszego syna Henryka starał się o rozkwit majątku. Henryk Dembiński wystawił mu piękną laurkę, pisząc:

Będąc nadleśniczym [Rudke] wykazywał już duże zdolności w administrowaniu gospodarką leśną i dlatego powierzono mu stanowisko nadleśniczego. Z obowiązków swoich wywiązywał się z całą znajomością rzeczy i fachowością dobrego leśnika, a jako samodzielny i uczciwy kierownik wykazywał dużo inicjatywy, z największą wydajnością prowadził eksploatację i przeróbkę drewna. Odnowienie i pielęgnacja były prowadzone wzorowo, dowodem czego pozostały piękne młodniki i podszyty jodłowe. Poza tym wybudował kilkadziesiąt hektarów stawów rybnych i prowadził wzorowo gospodarstwo karpiowe ${ }^{43}$.

W okresie ludowej Polski jego wojenne kontakty z Niemcami stały się podstawą do oskarżeń o współpracę. Zarzucano mu, że gościł przedstawicieli gestapo i żandarmerii niemieckiej u siebie w domu, pił z nimi wódkę, donosił na Polaków ${ }^{44}$. Rudke wyjaśniał:

Podczas mego pobytu w Rozwadach bardzo często przyjeżdżali na polowania Niemcy z Opoczna i Tomaszowa i po skończonych polowaniach zajechali do mego mieszkania w celu pożywienia. Jednocześnie częściowo mieli swoje, częściowo dawałem

43 ARDLP, Zaświadczenie Henryka Dembińskiego potwierdzone przez notariusza, Warszawa, 13 września 1948.

44 IPN/Bi/oo88/550/D, s. 4, Pismo do Szefa Urzędu Bezpieczeństwa Publicznego w Olsztynie 1953 r. 
ja, mieli również wódkę, którą wspólnie przy jedzeniu pili oni i ja. Rozmowy w tym czasie, jako myśliwymi prowadziłem na temat polowań i o pracach leśnych z leśnikami. Poddaństwa niemieckiego, do czego byłem zmuszany przez gestapo, nie przyjąłem. Z rodziny mojej również nikt nie przyjął listy narodowości niemieckiej ${ }^{45}$.

W innym miejscu w życiorysie opisywał ciekawą sytuację. Otóż w 1943 r. przyjechał do niego gestapowiec, który twierdził, że Rudke jest Niemcem, bowiem ma niebieskie oczy i blond włosy, a także nazwisko, które o tym świadczy. Namawiał go, aby podpisał volkslistę. Po wyjaśnieniach, że jego prapradziad pochodzi z Finlandii, Rudke oświadczył: „Jestem Polakiem, takim się urodziłem i takim umrę"

Definicje pogranicza i tożsamości można opisywać wielowymiarowo i wieloaspektowo. Ich niejednoznaczność wyraża się w różnych perspektywach ${ }^{47}$. Nietuzinkowa postać Otokara Rudke odzwierciedla wiele z tych perspektyw:

- perspektywę psychologiczną (samoświadomość, poczucie własnej wartości, ugruntowana polskość);

- socjologiczną i narodową (współpraca z różnymi grupami etnicznymi i narodowymi, jak Żydzi, Warmiacy, Niemcy);

- geograficzną (przypisanie do terytorium, miejsca i przestrzeni);

- historyczną (życie na przestrzeni pięciu okresów historycznych: zabór rosyjski, Druga Rzeczpospolita, okupacja niemiecka, PRL, III Rzeczpospolita).

Po drugiej wojnie światowej Otokar Rudke mógł znowu poświęcić się pracy dla dobra lasu. Od początku osiedlenia się na podolsztyńskich terenach miał na celu uporządkowanie gospodarki leśnej i łowieckiej w regionie. Należał do jednych z pierwszych organizatorów Polskiego Związku Łowieckiego w Olsztynie. Nie zaprzestał polowań, które były jego pasją i umiłowanym zajęciem. Na początku lat dziewięćdziesiątych XX w., w związku ze złym stanem zdrowia, Otokar Rudke przeprowadził się do Warszawy do córki Celiny i wnuka Przemysława Kazimierza Sługockiego. Zmarł 4 lipca 1993 r. w wieku 91 lat z powodu udaru mózgu. Pochowany został na cmentarzu wojskowym Powązki w Warszawie, gdzie leżą też inni członkowie jego rodziny.

45 IPN/Bi/oo88/550/D, s. 73-75, Protokół przesłuchania podejrzanego, Olsztyn 2 III 1953 r.; tamże, S. 46, Dodatkowy protokół z przesłuchania podejrzanego, Olsztyn, 25 stycznia 1946 r.

46 IPN/Bi/oo88/550/D, s. 20, Życiorys z dn. 2 marca 1953 r.

47 M. S. Szczepański, Na peryferiach systemu światowego? Socjologiczna refleksja wokót miejsca pogranicza kulturowego $w$ układzie globalnym, w: Pogranicza etniczne w Europie. Harmonia i konflikty, red. K. Krzysztofek, A. Sadowski, Białystok 2001, s. 39. 
Streszczenie: Otokar Rudke to nadleśniczy żyjący i działający w obszarze pogranicza zarówno politycznego, kulturowego, jak i społecznego. Urodzony w rodzinie właścicieli ziemskich i przemysłowych, po drugiej wojnie światowej wyrzekł się swojego pochodzenia i określał się synem chłopa (pogranicze społeczne). W okresie przedwojennym pracował w Nadleśnictwie Przysucha (okręg kielecki), a po wojnie w Nadleśnictwie Kudypy (Warmia). Jego przodkowie pochodzili z rodziny fińskiej, on sam uważał się za Polaka, ale w czasie okupacji był namawiany do podpisania Volkslisty jako Niemiec. Nigdy się na to nie zgodził, jednak musiał pracować na Warmii, gdzie mieszkało dużo rodowitej ludności (pogranicze kulturowe). W młodości działał w PPS, po wojnie w PZPR. Szybko jednak został wyrzucony z partii, a przez władze komunistyczne więziony i zmuszany do współpracy z SB (pogranicze polityczne).

Słowa kluczowe: Otokar Rudke, pogranicza, biografia, Nadleśnictwo Przysucha, leśnik, rodzina, tradycje

\section{Bibliografia}

Archiwum Prywatne Rodziny Rudke i Sługockich.

Archiwum Regionalnej Dyrekcji Lasów Państwowych.

Instytut Pamięci Narodowej, Oddział w Białymstoku, zbiory zdigitalizowane.

Bokszański Z., Tożsamości zbiorowe, Warszawa 2006, s. 37.

Chodubski A., O tożsamości polonijnej, w: Tożsamość kulturowa, kwestie narodowościowe i polonijne, red. A. Chodubski, Toruń 1998.

Fafiński W., Referat wygłoszony na Xxx lecie koła, http://www.kudypy.olsztyn.pl/index.php/historia-kultura/41-historia/74-referat-wygoszony-na-xxx-lecie-kola-, dostęp: 28.03.2015.

Kłoskowska A., Tożsamość i identyfikacja narodowa w perspektywie historycznej i psychologicznej, „Kultura i Społeczeństwo”, 36 (1992) nr 1.

Lewandowska I., S. Szkamruk, Bobry i ludzie - wspólne oddziaływanie w środowisku historycznym i przyrodniczym Warmii i Mazur, „Zeszyty Naukowe Ostrołęckiego Towarzystwa Naukowego" (w druku).

Lewandowska I., S. Szkamruk, Otton Alfons (Otokar) Rudke 1902-1993. Początki powojennego leśnictwa, łowiectwa i bobrownictwa na Warmii, Olsztyn 2015.

Rudke O., Przysięgę odbierał hubalczyk, w: Gniewnie szumiał las. Wspomnienia leśników polskich 1939-1945, wybór i oprac. J. Gmitruk, W. Lipko, P. Matusak, Warszawa 1982.

Sakson A., Mazurzy - społeczność pogranicza, Poznań 1990.

Sługocki P.K., Wspomnienia o dziadku, Warszawa 2015, maszynopis w zbiorach autorek.

Szczepański M. S., Na peryferiach systemu światowego? Socjologiczna refleksja wokół miejsca pogranicza kulturowego w układzie globalnym, w: Pogranicza etniczne w Europie. Harmonia i konflikty, red. K. Krzysztofek, A. Sadowski, Białystok 2001.

Szumarski W., Wspomnienia o pierwszym powojennym nadleśniczym Nadleśnictwa Kudypy, maszynopis w zbiorach autorek. 